\title{
Wartime Folklore: Italian Anthropology and the First World War'
}

\author{
Paolo De Simonis and Fabio Dei
}

\section{Introduction}

The First World War ended a rather lively era in Italian anthropology. It had brought forth an abundance of studies of regional folklore, along with vastly heightened ethnological ambitions. But wartime scientific mobilization was practically nonexistent, and the years that followed saw little attention given to any anthropological questions the conflict might have raised. The 1920s and 1930 s in Italy witnessed an overall weakening of the social sciences tout court, both because fascist policy prevented international debate ${ }^{2}$ and because of the influence of the idealism of Benedetto Croce, with its rejection of the very notion of a "science" of man. Nevertheless, a small body of studies and collections of "war folklore"-the customs, beliefs, symbolic systems, and cultural practices that developed among soldiers at the front-offer a prism through which the relationship between Italian anthropology and the Great War can be discerned. Various scholars regarded the trenches as laboratories where processes of cultural creation, transmission, and change could be observed in real time. They classified and described discrete phenomena including songs, superstitions, forms of religious devotion, and linguistic habits, sometimes making them the objects of quite interesting interpretative ideas. The following pages analyze this literature and identify internal tensions that were not to find full expression until after the Second World War-a much more decisive juncture for anthropology in Italy than the First.

1 This chapter was cowritten by Paolo De Simonis (first three sections) and Fabio Dei (last three sections).

2 The notable exceptions were Raffaele Pettazzoni and Giuseppe Cocchiara. 
Our first section presents a synthesis of conditions affecting the anthropological disciplines in Italy before World War I and during the fascist regime. The second section examines the work of the physician, psychologist, and theologian Fr. Agostino Gemelli, a singular figure destined to become highly influential in Italian Catholicism, and the first to make systematic observations of war folklore. The third section reviews contributions on the favorite theme of popular wartime songs. Studies of religious beliefs, practices, and superstitions are discussed in the fourth and fifth sections, with emphasis on the critique of Fr. Agostino Gemelli by the folklorist Raffaele Corso. Their disagreement, touching on crucial interpretative questions, exemplifies the theoretical backwardness that remained problematic throughout the fascist era. The final section looks in more general terms at the problem of the relation between war and anthropological knowledge. By presenting the contrasting approach of the ethnologist and historian of religion, Ernesto De Martino, we will show that World War II brought about a real and radical epistemological rupture for the "human sciences" in Italy.

\section{Italian Cultural Anthropology}

The discipline of anthropology gained a foothold in Italy in 1869 with Paolo Mantegazza's university chair and was soon joined by the Italian Society of Anthropology and Ethnology, the periodical Archivio per l'Antropologia e l'Etnologia, and the National Museum of Anthropology. Mantegazza's anthropology was essentially physical, with cultural phenomena assigned to the domain of biology and subjected to naturalistic methods.

Giovenale Vegezzi Ruscalla ${ }^{3}$ had introduced the term "ethnology" in Italy ten years earlier, including in it the study of peoples "of culture" as well as "of nature." When attention within the discipline turned to the latter almost exclusively, Italian contributions were not lacking. Absent, however, was a framework for the elaboration of investigative findings, which often resulted in isolation. Italy's late and limited colonial adventures had failed to inspire an ethnology determined by the remorse of a "colonial conscience" or the "revolt of the ethnological object," as had happened elsewhere. Instead, it was civil institutions and their origins that aroused the strongest interest, a development favored by the strong tradition of classical studies of the Greco-Roman world. As the century progressed, scholars' attention increasingly became focused on regional popular traditions, especially songs and folktales-a practice that began in the Romantic era and was consolidated under the banner of positivist philology and

3 Giovenale Vegezzi Ruscalla, "Della convenienza di un corso di Etnologia," Rivista Contemporanea XVI (1859): 81-88. 
large-scale, comparative historical methods. But its position remained marginal; Italian identity did not center on a "popular national soul," but rather on the nation's medieval and renaissance literary and artistic heritage. Scholars, such as Constantino Nigra, Alessandro D’Ancona, and Angelo De Gubernatis, had gained their reputations in fields other than ethnology, perhaps another reason why their studies of songs and folktales were selective and compartmentalized. The "National Society for Italian Popular Traditions," with its publication Rivista delle Tradizioni Popolari, founded in 1893 by De Gubernatis, aspired to a more compact "cultural" conception, but was short-lived.

The beginnings of the twentieth century saw strategically convergent proposals beginning to take form, not least the investigative options cited above, along with the realization that physical-naturalistic methods could not extend to cover phenomena from human life. Race no longer determined culture, and cultural data had detached themselves from somatic data. In 1902, Aldobrandino Mochi expressed the need to take a closer look at "the people of our countryside, of the mountains, [...] of all those backward corners where civilization has not yet arrived." ${ }^{4}$ In 1905, Lamberto Loria asked,

Why do we go so far away to study the customs and habits of peoples, when we still do not know those of our own countrymen, politically united under the same government, but with a thousand different inheritances blended, or simply mixed, in their blood? ${ }^{5}$

A doctor from Palermo, Giuseppe Pitré, coined the term demopsicologia for "the psychology of the masses" and was appointed to its first chair at his hometown university in 1911.

The "First Congress of Italian Ethnography" was held in Rome in October of the same year. Accompanied by a major "Exhibition of Italian Ethnography," it was part of the "Universal Exposition" staged to celebrate fifty years of Italian unification. The $A c t s^{6}$ of the Congress indicate tendencies then current in the demo-ethno-anthropological sciences and suggest that different generations and disciplines engaged in animated discussions marked by a desire for openness, innovation, and research of greater scope and ambition. Calls to the anthropology of the Anglo-Saxon world-Edward B. Tylor, James G. Frazer, Robert R. Marett, and Edwin S. Hartland-can be clearly heard, chiefly from younger scholars, but also to the German school of P. Wilhelm Schmidt and

4 Aldobrandino Mochi, "Per l'Etnografia italiana," Archivio per l'Antropologia e I'Etnologia XXXII (1902): 645.

5 Lamberto Loria, "Del modo di promuovere gli studi di Etnografia italiana," Rassegna Contemporanea III, 7 (1905): 4.

6 Atti del Primo Congresso di Etnografia Italiana, Roma 19-24 Oct. 1911 (Perugia: Unione Tip. Coop., 1912). 
Rudolf Otto, particularly from Raffaele Pettazzoni. Hugo Schuchardt presented Wörter und Sachen, while Raffaele Corso invoked, despite opposition, Arnold Van Gennep. ${ }^{7}$ To conventional themes were added new ones-jargons, gypsies, and migration. In research on songs, it was considered vital that music be recorded using technologies then newly available. The ethnography presented-as the nonspecialist press noted and appreciated-"radiates outward into philosophy, art, music, history, anthropology, sociology, medicine, religion, geology, archaeology, and linguistics." Italiana came out a few months later, with an editorial by Loria promoting the discipline's usefulness for colonial administration and national policy.

Facts do not always follow intentions, however. Symbolic of this is the fate of the exhibition that should have rapidly been installed in the National Museum of Ethnography: In fact, it remained in storage until 1956, when it finally went on permanent display at the National Museum of Popular Arts and Traditions. During these decades, Italian anthropology suffered a period of stagnation-easy to verify, but more difficult to explain. Several leading figures, particularly on the cultural side, were lost in rapid succession. Lamberto Loria died in 1913, followed in 1915 by Francesco Novati, his successor as president of the Italian Society of Ethnography, and in 1916 by Giuseppe Pitré. But we can identify two more specific causes for the stagnation in folklore studiesone at the level of ideas and the other political.

First, the idealistic historicism of Croce negated philology and the new social sciences by rejecting causalism and generalization, considering them useful only as ancillary practices for purposes of ordering and classification. The only valid human science for Croce was history. His ideas had considerable influence from the turn of the century onward, and when under fascism they became hegemonic, folklore studies (according to the reading of Pietro Clemente ${ }^{9}$ ) tried to elude them either with syncretistic solutions (see below for the particular position of Vittorio Santoli) or by claiming to produce not science, but merely useful material for it. In other words, folklorists continued to live positivist practices and adhered only extrinsically to historicism. They survived like heretics converted only superficially to orthodoxy, condemned to an extreme marginalization.

Second, the fascist preference for peasant traditions over industrial modernity shrewdly parried early twentieth-century anxieties. Practices that had been dying out or changing (feast days and festivals, customs, and dances)

7 Alba Rosa Leone, "La Chiesa, i cattolici e le scienze dell'uomo: 1860-1960," in L'antropologia italiana: Un secolo di storia, ed. Pietro Clemente (Bari: Laterza, 1985), 133-134.

8 Vittorio Podrecca, "La storia dei poveri," Avanti!, October 20, 1911, 3.

9 Cf. Pietro Clemente, "Alcuni momenti della demologia storicistica in Italia," in idem, L'antropologia italiana, 3-49. 
were reconstructed as leisure activities, primarily for the benefit of tourists. Within the discipline, reactionary elements took center stage, placing nationalism, ruralism, localism, sexism, and so forth in the service of ideology and propaganda, with predictable results. In 1932, it was decided to "locate and discipline" the various initiatives connected with folklore "in the ranks of a decidedly fascist institution," ${ }^{10}$ the Italian National Committee for the Popular Arts. To reduce the foreign taint, the discipline was renamed "popolaresca." Raffaele Corso, the founder of Il Folklore Italiano (renamed Archivio per la raccolta e lo studio delle tradizioni popolari italiane), was among the signers of the Manifesto degli scienziati razzisti in $1938,{ }^{11}$ along with Giuseppe Cocchiara, who wrote various articles on the "Difesa della razza" and a controversial 1939 essay for the Zeitschrift für Volkskunde. Even exhibitions on the recently conquered Ethiopians and Eritreans celebrated Italian virtues. ${ }^{12}$ The fourth ethnological congress, held in Venice in 1940, was devoted to formulating arguments for Italian dominion over the Mediterranean. ${ }^{13}$ Emma Bona, editor of Lares, held it incumbent on researchers to gather evidence for the "irrepressible force and iron temperament"14 of the Italian people.

\section{War as Laboratory: The Contribution of Gemelli}

“The war," Giuseppe Vidossi would note in 1931,

with its psychology and mass movements, created extraordinary conditions that allowed-in folklore as in so many other fields-developments normally requiring long elaborative cycles to mature in a brief period of years. The wartime climate was, in this sense, similar to the artificial climate of a laboratory, where one attempts to reproduce natural phenomena in order to study them. ${ }^{15}$

10 Lares 3-4 (1932): 157.

11 Published in July, the Manifesto constitutes "scientific" support for the "Measures for the Defense of Italian Race"-a law approved in November of the same year by the fascist government which opened the way for the Jews' persecutions.

12 Historical and juridical surveys were conducted by Carlo Conti-Rossini and Enrico Cerulli.

13 Atti del IV Congresso Nazionale di arti e tradizioni popolari (Venice: Opera Nazionale Dopolavoro, 1940), 606.

14 In a letter dated March 5, 1941, cited in Stefano Cavazza, Piccole patrie: Feste popolari tra regione e nazione durante il fascismo (Bologna: II Mulino, 1997), 145.

15 Giuseppe Vidossi, "Folklore di guerra: Ex voto italiani," II Folklore Italiano, no. 6 (1931); later published in Saggi e scritti minori di folklore (Torino: Bottega d'Erasmo, 1960), 79. 
It was not folklorists, however, who performed the bulk of wartime fieldwork. The chaplain and medical officer Gemelli was perhaps the first to realize folklore's significance for the human sciences, writing that "this study, this collection of material, must be carried out from this moment on." ${ }^{16}$ But although he shared folklorists' sense of anguished urgency regarding ephemeral data, he did not share their training. Born in Milan in 1878 to a bourgeois family of radical Masonic inclinations, Gemelli frequented republican and socialist circles, enrolling in the medical school in Pavia and collaborating with the socialist weekly La plebe. In 1898, he organized meetings in Milan and took part in demonstrations, against the high cost of living, that were bloodily suppressed by General Bava Beccaris. He became acquainted with Roberto Ardigò in Pavia and became passionately interested in laboratory research. His military service after graduation was as a medical officer in a hospital, and it was there that his swift conversion to Catholicism took place. In defiance of his parents, he entered the Franciscan order. He studied biology and specialized in neuropsychiatry in Berlin, frequently staying in Bonn and Frankfurt to attend lectures in physiology and neurology. Ordained in 1908, he founded the Rivista di Filosofia Neoscolastica in 1909 and, in 1914, the cultural journal Vita e Pensiero, which upheld a return to theocentric positions. In the meantime, he pursued research in histology and experimental psychology and sought to establish a scientific basis for the miracles of Lourdes.

On Italy's entry into the war, his faith, abilities, and patriotism became one. Already nationally known, he entered into a variety of relationships with the Army General Staff, directing the high command's experimental psychophysiology laboratory and undertaking various tasks for the ethico-social section of the historiographic office. He suffered no hesitations as to the duty of Catholics to fight in the war, which he described in May of 1915 as "a terrible and severe eliminator of those peoples who have betrayed their mission, and an instrument in the hands of Providence." ${ }^{17} \mathrm{He}$ wrote prolifically on current affairs, publishing on topics running from lice in the trenches to war games played by children, from the effect of wind in spreading the sound of artillery to medical methods of selecting flight crews- "placing myself next to the subject to be examined during the flight, [...] I studied his pulse, breathing, and blood pressure and the changes to them during the flight itself." 18

16 Agostino Gemelli, Il nostro soldato: Saggi di psicologia militare (Milan: Treves, 1917), 6.

17 Idem, "Contrasti e paradossi della guerra: Le conseguenze benefiche della guerra," Vita e Pensiero I, p. 9, May 10, 1915, 529.

18 Idem, Sull'applicazione dei metodi psico-fisici dei candidati all'aviazione militare-Relazione di ricerche sperimentali compiute per incarico del Ministero della Guerra presentata al Congresso della Società per il progresso delle Scienze (Milan: Vita e Pensiero, 1917), 7-8. 
His central concern, however, was the mind and soul of the common soldier, which he believed would decide the outcome of the war. He was against the modern overvaluation of technical equipment, against the man-machine, almost consonant with the criticisms leveled at Fordist industrial production. "Man, above all the soul of man - that, and I would say that alone, constitutes today, as yesterday, as always, as it shall be tomorrow, the soul of the battle, the true factor in victory." ${ }^{19}$ Not confined to values, the "soul" of the Italian soldier included a hereditary knack for improvisation: "You see him erect kitchens, build shelters, make machinery work! With a piece of wood, a little cable, he knows how to rig up delicate instruments and in a short space he creates the modest comforts of his life." ${ }^{20}$ At the front, each soldier's native soul mixes with those of his comrades from other localities:

In songs, superstitions, etc., we have material that reflects in its freshest reality the simple soul of our soldier. This material also allows a comparative study among the regions where the soldiers were recruited, among the localities they are from [...]. The study of war folklore is thus a contribution to Italian folklore. ${ }^{21}$

Gemelli followed the emotional metamorphosis of the Italian soldier in situations proceeding step by step from the excitement of departure and the formative depersonalization of the barracks, to the battlefield sublimation into the collective "I" of the group. His method was unabashedly positivistic, employing direct observation and questionnaires. "I managed to pass the nerve-jangling hours of waiting and the epic ones of the trials, next to him in the front lines; I jotted down in my notebook even the simplest phrases that fell from his lips."22 Such fieldwork vaunted its stripping away of the armchair rhetoric of writers and journalists who were guilty of "a conventionality of the moment, for which a typical soldier is painted, one that in reality you will never meet." ${ }^{23}$ Gemelli aspired to show things as they were, not as they should have been:

I wanted to shine a light even on the base things, the pusillanimity, the deplorable tendencies that our soldier shows, and that are the effect of his earlier life [...]. The soldier is worth the same as the people from whom he comes, and so he brings to the battlefield the defects he had at home. ${ }^{24}$

Such explicit use of the transgressive reach of positivism found acknowledgement of very different kinds. Antonio Gramsci praised Agostino Gemelli's

19 Idem, "I fattori della vittoria," Vita e Pensiero I, p. 1, July 20, 1915, 19.

20 Idem, II nostro soldato, 21.

21 Ibid., 182-183.

22 Ibid., 8.

23 Ibid., 10.

24 Ibid., 12. 
resolve to reduce "the hero to a man who cries, is afraid, even while carrying out acts that-seen from afar and removed from hackneyed, day to day affairs-take on an epic greatness, something superhuman." ${ }^{25}$ For Gemelli, the dialectic of courage and fear was managed by a sort of alienation or disavowal that shielded actors from the agony of choice. "The soldier ceases to be 'he'; his 'I' is another; the life that he leads as a soldier is a parenthesis in his life; it is not 'his' life but another life to which he attaches little importance, and so he lives outside himself." ${ }^{26}$ Submission to hierarchies clearly formed part of the picture, but precluded heroism. Particularly in military spheres, the demythologization of the soldier-hero met with censure or even outrage: "Almost blasphemous" was the judgment passed on Gemelli by Lieutenant Colonel Francesco Lavagna. ${ }^{27}$

Gemelli was more than an impartial observer. When it seemed to him that the war, contrary to initial information, was not inspiring large numbers of soldiers to "return" to religion, he planned and directed a mass revival. On the first Friday of 1917, "having confessed and taken communion, over two million soldiers and sailors, with numerous officers of all ranks, consecrated themselves to the Sacred Heart of Jesus, wherever they were; in the trenches, in hospitals, in Italy, Albania, Macedonia, Libya." ${ }^{28}$ A triangular piece of material with the motto In hoc signo vinces and the words protezione del soldato was placed on the chest of each soldier, in part to counteract the use of amulets.

Gemelli's enthusiasm for folklore represented a mere phase in his varied career as a scholar, researcher, and man of the cloth-a rather short phase, but one of typical intensity, and his observations emerged as the most organic and least banal that the war would produce. After demobilization, his scientific and organizational activities continued unabated. In 1921, he inaugurated Milan's Catholic University, where he founded a modern psychology department. Of his commitment to the dictatorship, there can be no doubt.

No one can deny that fascism, both by recognizing that the Catholic religion is the religion of the Italian people and, with the full exercise of its powers, getting rid of Masonic sects and anticlerical parties, has brought about the conditions for the implementation of the Lateran Treaty. ${ }^{29}$

25 Antonio Gramsci, "La predica di frate Agostino Gemelli," Avanti!, Pag. Piemontese, April 29, 1916, 119.

26 Gemelli, Il nostro soldato, 103.

27 Vito Labita, "La psicologia militare italiana (1915-18)," in La Grande Guerra: Esperienza, memoria, immagini, eds. D. Leoni and C. Zadra (Bologna: II Mulino, 1986), 242.

28 Memoria di Padre Agostino Gemelli dei Frati Minori (Milan: Curia dei Frati Minori Lombardi, 1960), 45.

29 Agostino Gemelli, Introduzione a Chiesa e Stato (Milan: Vita e Pensiero, 1939), xi. 
After World War II, he was nominated to the higher council on public education, dedicating himself to the development of the university, where he became life rector in 1953. He died in 1959, ending his career with a tenacious campaign against the laicism that had marked its beginnings:

against the depravity of contemporary thought, whether it be called Croce or Marx, whether it be clothed as scientific thought, proclaiming itself as the affirmation of new conquests; we will do this, because we know we are defending our young people in the name of our parents. ${ }^{30}$

\section{Collecting War Folklore: Soldiers' Songs}

At first glance, the Italian bibliography relating to the musical folklore of the Great War appears decidedly full. But most of the items are collections in the Romantic tradition of preserving popular lyrics as storehouses of national values and even the studies by folklorists fail to notate tunes. The more contemporary philological, historicizing approach, with its interest in identifying origins and regional dynamics (or on Nigra's scheme, songs' position on a continuum from Celtic narrative songs in the north to the lyrical love songs of the Italic south), neglected wartime folklore. As Ermolao Rubieri noted in 1877, "an aversion to military life is predominant amongst the general moral characteristics of Italian popular poetry." ${ }^{31}$ Folklorists similarly did their best to ignore the war, and leading scholars of popular song, such as Michele Barbi and Vittorio Santoli, succeeded. Wartime conditions obviated the "distance" from which folklorists preferred to observe their subjects. Modern warfare was too dynamic, too contemporary and, above all, too destructive of "traditional" ways of life. It thus fell to others to collect, conserve or refigure, and (on occasion) study soldiers' songs-primarily official bodies, such as the Military History Office of the Army General Staff. On the frontispiece of the 1922 publication I canti del fante by Mario Griffini, ${ }^{32}$ for example, we read "Istituto storiografico della mobilitazione: Serie etico-sociale (folklore). ${ }^{{ }^{33}}$

Gemelli published I canti del nostro soldato: Documenti per la psicologia militare $^{34}$ in 1917. Consistent with his medical interests, he saw the songs as a diagnostic tool "to determine the contents of the psychic life of the soldier," ${ }^{35}$

30 Memoria di Padre Agostino Gemelli, 101.

31 Ermolao Rubieri, Storia della poesia popolare italiana (Florence: Barbera, 1877), 93.

32 Mario Griffini, I canti del fante (Rome: Alfieri e Lacroix, 1922).

33 Historiographical Institute of Mobilization. Ethical-social series (folklore).

34 Agostino Gemelli, I canti del nostro soldato: Documenti per la psicologia militare (Milan: Vita e Pensiero, 1917).

35 Ibid., 375. 
but held their primary function to be "psychophysiological." "Musical rhythm makes muscular effort easier, or at least prolongs it, as a well-known psychological law affirms, according to which muscular movements carried out rhythmically use up less energy." ${ }^{36}$ Gemelli had likely never examined popular songs in any detail, as indicated by his amazement at texts which "seem in the beginning tales of events, but then as the song goes on refer to the most various and odd things without any connection between them.." ${ }^{37}$ On the other hand, his naïve approach may have picked up on noncanonic elements that would have gone unnoticed by specialists, as, for example, when he suggests that certain couplets were composed by an Austrian agent. ${ }^{38}$

Canti di soldati raccolti da Barba Piero-Zona di fuoco, estate 1918, by Piero Jahier, a poet and literary man stationed as an officer at the front, was published in the trench newspaper L'Astico to broad acclaim. ${ }^{39} \mathrm{He}$ had observed his alpine troops attentively as they sang, noting that they wrote lyrics down and passed them around "like a letter from the beloved." But his aims were not merely descriptive. He saw a need to "discipline and direct this very evident love with a bit of schooling," teaching soldiers "the songs of free peoples, which give this war conscience." Another nonfolklorist, Arturo Marpicati, published La proletaria: Saggi sulla psicologia delle masse combattent $i^{40}$ in 1920. A writer who held political posts in the regime, Marpicati confessed to an ambition:

to produce work that is in a certain sense almost scientific: not-God help me-the science of pompous titles, sociology, demo-psychology and so on, but something humbler and perhaps truer, happy simply to collect, order and interpret the fruits of direct experience. ${ }^{41}$

One result was the decision-not entirely trivial-to present songs in order of the "formative" stages of the soldier: departure, barracks, trenches, and combat.

The work of the young ethnologist Giuseppe Cocchiara was still more detached from the events of the war, ${ }^{42}$ as was that of the ethnomusicologist

36 Ibid., 374.

37 Ibid., 376.

38 Ibid., 392.

39 Released the following year in book form as Vittorio Gui and Piero Jahier, Canti di soldati, raccolti da Piero Jahier tenente degli Alpini, armonizzati da Vittorio Gui, tenente del Genio (Milan: Sonzogno, 1919).

40 Arturo Marpicati, La proletaria: Saggi sulla psicologia delle masse combattenti (Florence: Bemporad, 1920).

41 Ibid., 5-6.

42 Giuseppe Cocchiara, L'anima musicale del popolo italiano nei suoi canti (Milan: Hoepli, 1929). 
Cesare Caravaglios. ${ }^{43}$ Neither study displays particular originality or profundity, instead they work through cases with standard inquiries on the nature, origins, and diffusion of popular songs. The brief succession of "studies" is concluded in 1937, with Guerra e folklore by Giulio Mele, ${ }^{44}$ a quasi-journalistic work lacking a disciplinary standpoint.

All the collections and studies betray an amateurish enthusiasm for labeling and sorting. With their typical "outsider" logic, the criteria throw more light on the observer than the observed, proposing distinctions between marching songs and songs of the barracks, the prison, or particular units; songs satirical, popular, original, amorous or "contaminated" in nature; and of warlike exaltation, of evasion or resignation, of rage. Griffini's "songs of the corps" were sung "during marches when different divisions met, or at the inn-a sure route to fistfights and jail." ${ }^{35}$ Improper songs are represented by their titles, if at all. ${ }^{46}$ Collectors emphasized the diverse regional origins of "the people," occasionally used to denote an ethnic substratum. The southern soldier "sings alone, out of melancholy, and then his song, by its nature, is not choral. The true choral artist is from the north." ${ }^{37}$ Interregional contacts affected traditional songs, sometimes with official encouragement. Griffini noted that "Jahier has the great merit of having spread the Friulian villotte folk songs to the divisions from other lands. This is very difficult with dialect songs-the beautiful Sardinian songs have not gone beyond the Sassari brigade." ${ }^{48}$ The soldiers preferred more familiar fare: "Common songs come with satirical stanzas, almost all modeled on one of three originals: Sor Capanna, Petrolini, Bombacè (in order of time)." ${ }^{39}$ Interestingly, Petrolini was an art song linked to Futurism, the theater and the Café-chantant-perhaps all the more amenable to general acceptance. The exchange of songs had important consequences for analyses focused on diffusion and regional types. Gemelli had noted how the propagation of songs along the front followed the movement of divisions, and Santoli observed in 1930 that:

rather than the adaptation of parts of traditional songs to the circumstances of the time, the Great War had the effect of spreading the songs of different regions into areas where before there had been no trace of them, because it forced large numbers of people from various parts of Italy into contact with one another. ${ }^{50}$

43 Cesare Caravaglios, I canti delle trincee: Contributo al folklore di guerra, Introduction by Raffaele Corso (Rome: Leonardo da Vinci, 1930).

44 Giulio Mele, Guerra e folklore (Naples: Pironti, 1937).

45 Griffini, I canti del fante, 59.

46 Ibid., 4.

47 lbid., 3.

48 Ibid., 4.

49 Ibid., 3.

50 Vittorio Santoli, "Nuove questioni di poesia popolare (a proposito di una raccolta di canti toscani)," Pallante: Studi di filologia e folklore 5 (1930); also in 
More precise considerations of songs' origins were delayed and dismissive. "Who composed them? Nobody knows. The artist is the people taken together." 51

Folklorists applied late Romantic aesthetics to "the divine ingenuity of the war song, the unadorned elegance of epic singing," 52 but even militarist authors had to admit that "in such a war, there could not have been popular songs in which courageous colored flags waved, shaking with loyal disdain, in which shone a winged desire for adamantine glory." ${ }^{33}$ They soon "discovered" that heroism need not be expressed literally. In the anguish that preceded a decisive assault, Griffini writes:

a small infantryman softly sang "Quanto è bello far l'amore." It was an appeal to life; doubt and tiredness disappeared; we were all hate and anger-it was our love that we were defending — and we sprang out, injured, cut up, famished as we were. And we won. ${ }^{54}$

In sum, Italy's folklorists disregarded the war, missed every opportunity to verify observations or calibrate methods, and shared the task of producing simplified, ideologically rectified readings with outsiders to the field. War songs were "imagined" as being what they should have been-jingoistic material. Wartime propaganda had primed the pump by advocating musical continuity with the Risorgimento. In September, 1915, for example, a competition was announced in Florence for new songs in the local style that could be "compared, for sincerity and freshness, with many of those that our fathers sang as they moved impetuously from homes all over Italy in the wars of independence." 55 Three years later, the command of the Third Army publicly requested a hymn that would "have a very simple form and structure, as is proper for a popular song to be sung chorally." "It is necessary"-Marpicati held-"that the recruits know the hymns of the country by heart. The officers from the 94 th Infantry have had the good idea of having an hour's daily patriotic singing with their men," 57 although Griffini noted the "strange phenomenon that the infantryman is absolutely ignorant of what we might call official songs." 58 "All

idem, I canti popolari italian: Ricerche e questioni (Florence: Sansoni, 1968), 39.

51 Marpicati, La proletaria, 44.

52 Vincenzo M. Fontana, I canti delle trincee (Novara: E. Cattaneo, 1936), 3.

53 Marpicati, La proletaria, 46.

54 Griffini, I canti del fante, 2.

55 Rispetti e Stornelli Patriottici Toscani (Florence: Casa editrice La Nazione, 1916), 3.

56 Caravaglios, I canti delle trincee, 269.

57 Marpicati, La proletaria, 50.

58 Griffini, I canti del fante, 3. 
the songs compiled by officers," Cocchiara maintained, "never attained much popularity with the infantryman, and so they died before they were born, so to speak," ${ }^{29}$ while satires were presumed to originate in the officer's mess and spread to the ranks through the kitchens. Another apparent mode of vertical transmission was the songbook: Already in 1915, Il canzoniere del soldato offered sixty-four pages of "close print [...] at the tiny price of a simple postcard," to be mailed "in an open envelope with a two cent stamp." At home, "mothers, wives, fiancées, and sisters [...] marked with a pencil the poems they held most dear, as if to say 'they speak for you [...] we wish we had composed them for you.'"'60

After the war, as commemorations devoted to the construction of national memory declined in number and frequency, singing was relinked to leisure and socializing, with skiing and hiking clubs borrowing repertoires from the canzonieri. The songs regained their bellicose function for the 1936 conquest of Ethiopia. Mele described how "old, nostalgic war songs have been dug up, witty and defiant themes of memorable alpine songs" diffusion in the popular press. "You saw these songs hung like multicolored bunting on Neapolitan stands and stalls [...]. Some became very popular [...]. Now, the war having finished, the patriotic muse falls silent again." ${ }^{62}$ After World War II-and less than ten years later-Mele returned to publishing war songs, in this case those of the partisan resistance. With blatant trasformismo, he pays his homage in familiar terms: "The songs of the soldiers have a special function, moral and ideological, which using a scientific term we could better call psychophysiological. The song, with marching rhythm, gives impetus to the body and wings to the soul." ${ }^{3}$

\section{Wartime Superstitions: The Corso-Gemelli Debate}

Reflection on wartime folklore peaked with the debate on superstition between Gemelli and the folklorist Corso. Gemelli had collected material on superstition, which he defined as "the complex of beliefs and practices belonging to ancient religions, primitive and inferior, [that] had not totally disap-

59 Cocchiara, L'anima musicale, 293.

60 S. G. Girola, Il canzoniere del soldato: Rime d'amore e canti guerreschi (Como: Ist. Tip. A. Volta di Caccia e Corti, 1915), 2.

61 Mele, Guerra e folklore, 137.

62 Ibid., 138.

63 Raffaele Corso, "Introduzione," in Caravaglios, I canti delle trincee, cited in Giulio Mele, "Canti partigiani," Folklore 1 (1946): 39. 
peared but persisted." ${ }^{4}$ This evolutionist definition is curious and perhaps contradictory, given that Gemelli assumed the birth or resurgence of superstition in war. Superstitions could well be drawn from an ancient, fragmentary repertoire of survivals, but for Gemelli they were activated by current psychological motives. The trenches were particularly "favorable for the study, I would say almost in an experimental way, of the growth and propagation of superstitious practices," for at least two reasons. First, they imposed isolation on groups of soldiers constrained to live incommunicado and in mortal danger for long periods. Second, "the mixing of soldiers from different regions allowed for the transmission of traditions, beliefs, and customs from different regions." 65 The first factor was prominent in international literature; Marc Bloch, to name only the best-known example, saw isolation as the key factor in the birth of "false news" about the war. ${ }^{66}$ The second factor is specific to the situation of the Italian army, where regional linguistic and cultural differences were very marked. Gemelli describes mixing here as a sort of mythopoietic multiplier, using the suggestive image of "contagion." ${ }^{67}$

Gemelli's empirical material is laid out in typically positivist classificatory fashion. He began by distinguishing collective from individual superstitions as well as practices from beliefs, such as legends, prophecies, and omens. We see themes not far from Bloch's "false memories," with examples emphasizing the rapidity and scale on which the content of the legend spread. Practices were divided into remedies of magical-religious character, protective or therapeutic magical formulae, amulets, and prayers (in chain letters, scapulars, and the like). Gemelli gives short examples for each category, along with a comparative case history, including references to folklore studies, particularly French ones (the classics of British anthropology, such as Tylor and Frazer, are cited in French translation). For example, the habit of driving a nail with a protective function occasions an ample comparative digression, evolutionist in style, proceeding from the ancient world to ethnological cases in European folklore. Gemelli here appears attracted by the ethnographic and comparative approach, but feels the need to maintain distance. His interest focuses not on the diffusion or remote origin of popular beliefs and practices, but on the conditions of their resurgence in the context of war, and he insists on the specific nature of the psychological approach.

What, then, is his psychological interpretation? Here, Gemelli looks to a theoretical framework outside the Italian positivist tradition, based on the

64 Gemelli, II nostro soldato, 142.

65 Ibid., 141.

66 Marc Bloch, Réflexions d'un histoiren sur les fausses nouvelles de la guerre, 1st ed. (1921; repr. Paris: Allia, 1999).

67 Gemelli, Il nostro soldato, 148. 
vitalism of Henri Bergson and the phenomenological psychology of Pierre Janet and Théodule Ribot. Recourse to superstition, he argues, is a cultural technique that relieves the individual of responsibility for making decisions in difficult or dangerous situations-in the language of Janet, a technique for the maintenance of "the reality function" through mechanical behavior (heterodirected, with tradition overriding individual choice) that avoids excessive expenditure of psychic energy. Thus, "superstition subtracts the soldier from the necessity of taking a decision that he would be incapable of taking because of an insufficiency or inadequacy of psychic energy." 68 The soldier in wartime is analogous to the "many squeamish, apathetic, psychasthenic sick people, who with their manias and habits have recourse to objects and votives, simply to avoid being obliged to decide in the various circumstances of their lives." 69

The argument suffers from a fundamental weakness: Gemelli is well aware that new recruits arrive at basic training in possession of a stable and articulated folkloric repertoire. The claim that superstitions are "born" or "reborn" in wartime clashes with the notion that they are permanent and long-lasting dimensions of "popular mentality." Gemelli reacts by introducing, alongside the thesis of the protection of the reality function, an intellectualist theoretical framework that bases superstitious beliefs and practices on primitive thought of a magical or participative type, that survives in modern times only in the most backward social strata. Primitive thought provides "collective" beliefs with a foundation, while psychological-existential functionality explains individual religious devotion. Clearly, the two theories cannot comfortably live side by side, since they presuppose very different models of human rationality.

Corso's critique targeted exactly that point. A follower of Van Gennep at the time of the Rome Congress, he would become one of the folklorists most openly allied to the fascist regime and its ideology. ${ }^{70} \mathrm{He}$ dedicated the introductory lecture of his course in ethnography at the University of Rome in December of 1919 to a critique of Gemelli, published in 1920 in the religious studies journal Bylichnis. ${ }^{71} \mathrm{He}$ seems primarily concerned with defending the discipline from psychological approaches, addressing as well the theses of the French scholar Albert Dauzat, author of a monograph on war folklore. ${ }^{72}$ For Corso, such inter-

$68 \mathrm{lbid}, 174$.

69 Ibid.

70 Cavazza, Piccole patrie, 105-106.

71 Raffaele Corso, "La rinascita della superstizione nell'ultima guerra," Bylichnis 9 (1929): 81-98.

72 Albert Dauzat, Legendes, prophéties et superstition de la guerre (Paris: Le Renaissance du Livre, 1919). Corso referred to Gemelli and Dauzat as "the two psychologists." In reality, Dauzat was a linguist, although he claimed to consider the problem of war folklore from the perspective of "social psychology." Corso shows no evidence of having appreciated the strongest and 
pretations are nothing but variants of nineteenth-century theories that rooted religion in man's dread and awe at the power of natural phenomena. For "modern" psychology, magical thought and behavior in wartime are pathological.

The fighting man, faced with the danger, anxiety, and trepidation of the moment, would be constrained to substitute mechanical for voluntary action, and so his thought would take refuge in the ravines of antiquated tradition, making involuntary use of them. ${ }^{73}$

Against this thesis, Corso proposed the classical model of evolutionist intellectualism in which "superstition, considered ethnographically, is not the fruit of that sad tree of terror [...] but rather of thought in constant evolution." ${ }^{74}$ In other words, superstition is a manifestation of magical thought in a Frazerian sense-not anomalous thought or behavior in response to extraordinary situations, but a "normal" attempt (however fallacious or illusory) to understand and influence the world.

In consequence, Corso thought it misleading to isolate the phenomenon of wartime superstition from superstition in general. To assume that superstitions arise with particular force in wartime means to ignore their prior and ordinary diffusion, violating the spirit of a genealogical investigation. The latter can easily show that wartime superstitions do nothing more than reprise beliefs and practices already widespread in popular mentality. "Although observed at the edge of the trenches and battlefields, superstition is not a product sui generis, a fact deriving from the mentality of the moment, in this case warlike, but rather the exponent of the many and varied common popular traditions." 75 War brings no rebirth of superstition, but merely reflects its permanence.

The man who carries a weapon in his hand and fights on the borders of his fatherland does not forget, does not leave behind him [...] the traditions of his lands and his lares. His prejudices are those that populated the mind and the home of his ancestors. ${ }^{76}$

To sum up, for Corso, a cultural particularity of the wartime context, one that could make it into a special anthropological laboratory, did not exist. The diffusion of superstition amongst the soldiers could be simply explained by their origins in the "people," specifically the peasantry-"the countless pollen of plebeian superstition, transported by the wartime air, spread from life in the

most original element in Dauzat's position, the attribution of legends and superstitions to a collective dimension of cultural creation.

73 Corso, "La rinascita della superstizione," 84.

74 Ibid., 85.

75 Ibid., 86.

76 Ibid. 
fields to that in the battlefields, where it seemed to seed and flower, almost as a rebirth." But that "birth" is only an optical illusion, Corso believed: In fact, all superstition derives from the unmoving substratum of magical thought, primitive and prelogical (he cites James G. Frazer as well as Lucien LévyBruhl), that has never ceased to dominate the cultural life of the lower classes. On the one hand, Corso reasserts the crucial role of the anthropological conception of culture against what we might call the psychological reductionism of Gemelli. On the other hand, his anthropological comprehension does not go beyond an evolutionist model of primitive thought. His essay continually revolves around the metaphors of the "evil plant" and of the "disastrous illusion" of magic, crudely representing the popular world as immersed in prejudice and error.

Paradoxically, the psychologist Gemelli presented a more promising anthropological theory, extracting the relationship between culture and what today we would call human agency from evolutionist metaphysics. Influenced by Janet and Ribot, Gemelli reached an intuitive understanding of ritual's functional role in domesticating the world. Although in a fragmentary and sometimes contradictory way, he lays the foundations for overcoming the positivistic idea of "superstition" that had been developed to classify folk errors and prejudices and sketches a connection between cultural rites and symbols and individual identity, the construction or protection of Self as an active decision-making center. What Gemelli attempted to talk about-without finding suitable terms - was the modern anthropological category of symbolic efficacy. Reflections on the war led him to articulate a vitalist psychology and cultural theory, a road that would be much followed internationally in succeeding decades.

That road, however, remained off limits to Italian culture. After the publication of Il nostro soldato, Gemelli devoted himself to quite different intellectual projects, concerned less with linking anthropology and psychology than with linking Catholicism and fascism. With regard to anthropological and folklore studies, Corso's eloquent critique terminated the discussion.

\section{Gathering, Classifying, and Creating Collections}

The fascist era continued to produce reflections on war folklore, but they employed a philological, classificatory approach far from the sweeping theories of the "science of man." In what follows, we consider two examples: Giuseppe Bellucci on amulets and Cesare Caravaglios on "the religious soul of war."

The chemist Bellucci was an avid collector of paleologic and ethnographic remains. His collection of fetishes and amulets today forms an impor- 
tant museum in Perugia. He dedicated two books in the early 1920s to war folklore, ${ }^{77}$ making superstition and attendant objects, like fetishes and amulets, his dominant theme. His chief interpretive category is "mysticism," defined as a "primitive philosophical form, well-adapted to infantile or abnormal minds, incapable of reflection or obedience to the principles of reason." Wartime conditions provoke the primitive mindset to reappear-creating, for the author, a sudden atavism.

Faced with social disturbance on such a large scale and so profound, mysticism necessarily appeared in the most varied forms, becoming utterly evident in the different collective units of the warring peoples [...]. The superstitious mentality, which is that of prehistoric peoples and which remains more or less manifest in all peoples, reawakened as in all turbid epochs, and produced an ample mass of phenomena analogous to those which came about in antiquity, when civil progress was less accentuated and demonstrations of barbarism easier. ${ }^{78}$

More than the continuity between beanfields and battlefields, Bellucci was interested in the historical or evolutionary permanence of superstition and its reemergence in wartime. Substantially unalterable, superstition lies buried in "civilized" times, raising its head as conditions of barbarism permit. "Legends, prophecies, prejudices, collective means of protection; individual means of protection or defense; means to guarantee the attack on the enemy; amulets; songs; war cries; ironic expressions"-such elements did not spring from the current circumstances, but "were recalled from previous periods of warfare, returning to flower again when the conditions of social life corresponded to those of the past"79 with minor adjustments for technological progress. In the folklore of the Great War, "reminiscences of a past, one whose primordial beginnings arose in a very ancient time" coexist with "beliefs formulated in the present." Amulets made of prehistoric stone can coexist with others "formed of the copper rings from poison gas grenades." ${ }^{0}$

But evolution and syncretism take second place to the immobile unity of the primitive mind. Talking of the protective use made of projectiles taken from the bodies of the wounded and of parts of dead bodies-a custom also documented in previous wars-Bellucci remarks "that the human brain, finding itself in the same condition, even though distant in time, felt exactly those vibrations that had resonated before, manifested itself with the same thoughts,

77 Guiseppe Bellucci, Folklore di guerra (Perugia: Unione Tipografica Cooperativa, 1920); idem, I vivi ed i morti d'Italia nell'ultima guerra (Perugia: Unione Tipografica Cooperativa, 1920).

78 Idem, Folklore di guerra, 8.

79 Ibid., 9, 13.

80 Ibid., 14. 
and showed the same faith in corresponding objects." ${ }^{11}$ Here, an idea of polygenesis starts to intrude, allowing beliefs and practices from diverse times and places to be juxtaposed without regard to their cultures of origin. Italian or German, Catholic or Protestant, urban or rural: All soldiers belong to the subaltern classes, and all are alike immersed in vast, motionless reservoirs of magical-mystical thought.

Having laid down these premises, Bellucci sets about describing his examples, classified by type of belief or object according to function, material, and morphology. He relies on personal observations and his own collection as well as a small European bibliography. Several chapters cover the folklore of soldiers from other European countries, including Austria-Hungary, France, England, and even neutral Switzerland. As often happens with authors of the period, sensitive descriptions contrast with the poverty and ingenuousness of his interpretative categories. A genuine affection for amulets leads him to detail their profound human significance, in implicit denial of their "barbaric" character, so that his account retains some usefulness for studies of culture or "mentality."

While Bellucci died in 1921, Caravaglios lived to embody all the ambiguities of the compromise between folklore studies and the regime. His major 1935 work on religious war folklore ${ }^{82}$ is a singular admixture of interesting documentary and philological material and nationalist and prowar rhetoric, of sensitivity toward forms of popular devotion, and utilitarian reflections on how to place faith in the service of victory. The material is organized under headings, such as "cult practice at the front," "amulets and relics of war," "wartime ex-votos," and so on. A concluding section analyzes letters from troops at the front. Each category of cultural practice is then subclassified using sundry criteria. Votive offerings, for example, are divided by morphology: (a) those that reproduce parts of the ailing, injured, or frozen body that were cured; (b) weapons, one's own or the enemy's, offered to the divine protector, generally the Madonna; (c) clothing worn by the soldier at the moment of danger; (d) written messages, such as letters or dedications on photographs; (e) paintings; and (f) collective offerings, such as the erection of shrines. These religious forms "of the most humble" draw on the resources of primitive mentality. While admitting their superstitious character, Caravaglios does his utmost to demonstrate their compatibility with the authentic religious spirit and a "healthy faith" linked to patriotic self-sacrifice.

While highly respectful of Gemelli, he repeats Corso's criticisms, but misunderstands them, trying to mold them into an antirationalist fideism. Ritual protective practices are due "more than as a substitution of the involuntary for the voluntary, or a more or less greater abdication of individual will, to

81 Ibid., 106.

82 Cesare Caravaglios, L'anima religiosa della guerra (Milan: Mondadori, 1935). 
the need to link oneself, in the moment of danger, to the Supreme Being." ${ }^{33}$ Admittedly, the soldier hopes to survive unharmed, but the religious sentiment is authentic even when unaccompanied by an adequate education-for Cesare Caravaglios (citing Joseph De Maistre), one that unites the religious with the military spirit, locating the supreme value and spiritual objective in self-immolation for the Fatherland. ${ }^{84}$

With Caravaglios, we take a retrograde step that Corso and Bellucci had only hinted at. Hoarding and classification go hand in hand with the abandonment of any pretensions to "scientific" analysis of cultural processes, now replaced by nationalist rhetoric, or rather with the ideology of the regime.

\section{Reestablishing Presence: De Martino}

Theories of power after Michel Foucault have favored sexuality, deviance, illness, and punishment over military topics as subjects of analysis. Yet "total war" was surely the culmination of the dream of making the human body and soul into a wholly malleable instrument, its mass armies at one with the machine-body of the nation. The human sciences eagerly joined the fray, which required redefining the relationships between individual and collective conscience, pragmatic rationalism and political emotion, and the collective unconscious and motivation. But the human sciences were not merely enforcers of the state's cultural dominion, nor were they a simple ideological reflection of power. They consciously attempted to enable "self-discipline" that would relieve state power of the need to impose itself by force, but, at the same time, their disassembly of mechanisms of cultural and moral conditioning also laid the foundations for a critique of that power.

In the years following the Great War, this critique took the form of a "culture of crisis" which, while primarily literary and artistic in its manifestations, had its foundation in the human sciences. Anthropology and psychoanalysis (The Golden Bough and Totem und Taboo were widely read) had an enormous influence on modernist culture and on its efforts to reestablish the sense of history and humanity the war had so radically questioned. Referring to the poetics of the "mythic method," understood as "a way of controlling, of ordering, of giving shape and a significance to the immense panorama of futility and anarchy which is contemporary history," T. S. Eliot wrote in 1932 that "psychology [...], ethnology and The Golden Bough have concurred to make possible what was impossible even a few years ago." ${ }^{85}$ Between the wars, it was the social

83 lbid., 157.

84 Ibid., 158, 160.

85 T. S. Eliot, "'Ulysses,' Order and Myth," The Dial (November, 1923); also in Selected Prose of T. S. Eliot, ed. Frank Kermode (London: Faber \& Faber, 1975), 175. 
sciences that sustained a profound reconsideration of notions of progress and the relationship between the individual and society as well as reflection on the roots of violence and its connection to civilization.

In Italy, however, that potential remained unrealized. Corso and other folklorists turned to The Golden Bough, on the contrary to Eliot, as a dogmatic and antimodernist weapon. Harking back to the unmoving substratum of magical thought that dominated the lives of the lower classes (including soldiers), they placed them outside history, making them instead participants in natural evolution. The scholars were aware that soldiers in the trenches were engaged in the destruction of a world and that they lived with the unbearable, inescapable presence of death, but where Gemelli saw their resistance as a subjective creation of meaning, the folklorists regarded soldiers as an inert mass, passively reproducing a timeless mythical matrix. There is no drama of subjectivity, no process involving cultural dynamics to be understood, but simply cases to collect, conserve, and classify. No specific problem arises regarding the culture of soldiers, Corso tells us; they are merely displaced peasants. He reasserts the purely philological nature of his discipline, which can only proceed horizontally, collecting instances of the eternal, primitive mentality in which the people are submersed. One effect was to reify the gap between the "people" and the upper or intellectual classes. The latter go to war; the "people" are their tool.

The environment of fascism served to exacerbate the interpretive closure still further, carrying the folklorist and philological discourse toward an evermore striking superficiality and prowar rhetoric. The mating of research and ideology spawned curious and disturbing hybrids. As noted above, in L'anima religiosa della guerra, Caravaglios melds meticulous documentation with nationalist zeal in a truly singular way. The book begins with a sensitive evocation of a wartime existence dominated by looming death and chaos, seeming to cast doubt on the rhetoric of heroism. But we soon discover that he simply wishes to play up the role that folklore beliefs can play in calming and controlling the terrorized masses. In particular, it is beliefs about the soul, briefly summed up à la Frazer, that counteract the fear of death and reconcile soldiers to a war of mutual assured destruction.

Peoples of every time, every place and every civilization have at the foundation of their moral life the idea of the immortality of the soul. This gives us to suppose that if we could develop this healthy idea amongst our people, we would have a spiritual improvement amongst our masses and, more importantly, we would resolve, in the case of war, the so-called problem of fear, which could more properly be called that of attachment to life. ${ }^{86}$

86 Caravaglios, L'anima religiosa della guerra, 34. 
Again,

if we manage to implant in the soul of the fighting man the idea that life is not only physical, vegetative, that it does not finish with the dissolution of our body, but that we could live it in a better way, we will succeed in convincing him that should he die for the Fatherland, his death would be the safest way to ascend to the immortal heavens. $^{87}$

Here, the practical task for an anthropology of war is outlined: to create soldiers free from that fastidious nuisance of an attachment to life, ideal servants without the fear of death. The figure of the model soldier-or rather of the suicide bomber duped by cynical handlers-emerges forcefully from this explosive pastiche of militarist nationalism, fideism, and anthropological research, disguised as a dispassionate and erudite documentary collection.

To arrive at a new attitude, anthropology in Italy would require World War II-although it must be said that philological positivism sat out some of its bleakest moments unfazed. Vidossi entrusted to Lares his remarks on the "new traditions" and processes of folklore creation in wartime, his protagonists this time were not soldiers, but civilian evacuees from cities menaced by shelling or air raids. In Turin, he observed the practice of attaching sacred images to the facades of houses and bomb shelters. The variations among families by regional origin fascinated him. He describes his system of index cards, lists superstitions linked to comets, and cites stories of visions foretelling the end of the war in no particular order. ${ }^{88}$ The incongruity between the drama of the situation and the collector's zeal is almost grotesque. He seems unperturbed by the apocalypse unfolding before his very eyes-as if the self-destruction of Europe, the collapse of the very "civilization" that defined him as an "intellectual," had nothing to do with him.

With the recognition of this irony, a quite different mode of anthropological reflection began, epitomized by the work of De Martino, perhaps the most important figure in the reestablishment of the Italian social sciences after World War II. "Our civilization is in crisis-one world seems ready to fall to pieces while another is waiting to take its place," he wrote in his first book, published in $1941 .{ }^{89}$ A pupil of Croce, he pursued a historicist critique of ethnology's naturalist tradition. His first book was a critical examination of canonic authors and ideas from Émile Durkheim to Lucien Lévy-Bruhl, from

87 Ibid., 37.

88 Giuseppe Vidossi, "Appunti di demopsicologia di guerra," Lares XIV (n.s.) (1943); idem, in Saggi e scritti minori di folklore (Turin: Bottega d'Erasmo, 1969), 413-415.

89 Ernesto De Martino, Naturalismo e storicismo nell'etnologia (Bari: Laterza, 1941), 12. 
P. Wilhelm Schmidt to American anthropology; all were found guilty of naturalizing cultural facts and thus removing them from the comprehension of historical intelligence.

De Martino spent the war years developing a historicist approach to a classic anthropological theme, that of magic. Il mondo magico (1948) argues against theories grounded in a dogmatic, ethnocentric notion of "reality" that see the essence of magical thought in its illusory character. Rather, magic creates its own reality on the basis of a "historic drama" peculiar to itself-the crisis and cultural redemption of "presence." "Presence" for De Martino is the unity of the self and the active autonomy of the individual vis-à-vis the world and others. A fundamental good that our culture takes for granted, presence is a historical formation. There was an epoch - that of magic - in which presence was not guaranteed. It had to be defended and reaffirmed by the community time after time, whenever it faced pressure from the "negative." Even now, when the "negative" becomes menacing, presence can enter into crisis and require redemption by ritual and symbolic actions.

The categories used by De Martino have their roots more in phenomenology than in classical historicism, and Croce himself reproved him on that point. In particular, Janet's "reality function" is a principal source for De Martino, as it had been for Gemelli. De Martino never wrote explicitly of the rites or symbols of war, nor of the existential condition of the soldier. But it is difficult to avoid the impression that the drama of presence lost and regained, recounted in his book, relates to the tragedy of the war, with its dissolution and reconstitution of the Western subject. The world of magic is an archaic one, but it can manifest itself in the present: "In a situation of particular suffering and privation, during a war, a famine, or the like, being may not be able to resist the exceptional strain and so open itself again to the existential magic drama." ${ }^{90}$

One commentator has noted that the cultural crisis and redemption of the presence is the peculiar way in which De Martino talks about the "contemporary crisis" linked to the war.

What is happening is a type of transfert: the unexpressed emotional load is projected onto the object, the lability and precariousness experienced in the present become the essential constants of the magical world [...]. This transfert acts in such a way that il mondo magico constitutes, in a sense, a "redemption of presence" in the western world. ${ }^{11}$

90 Idem, Il mondo magico: Prolegomeni a una storia del magismo (Turin: Einaudi, 1948), 156.

91 Cesare Cases, "Introduzione," in Ernesto De Martino, II mondo magico, 2nd ed. (Turin: Boringhieri, 1973), p. xxv. 
We are a long way from the idea of war as a laboratory. The positivist distinction between subject and object defines the laboratory, and the folklorists' contributions gaze across a chasm that divides intellectuals guided by reason and faith in progress from a "people" dominated by an archaic and irrational culture. The former think, the latter live-or die, if the Fatherland so desires. For De Martino, on the other hand, war is the destruction of any possible laboratory. Faith in progress cannot survive unaltered where the world lies in ruins. It is with this reflection that anthropology reasserts its presence at the end of "the European civil war"-a historiographic category recently proposed by Enzo Traverso that, while open to debate, reflects the coherence of the period 1914-1945 also on a cultural level..$^{92}$ Anthropological reflections on the Great War remained closed in the dogmatism, ideological compromises, or nationalist enthusiasms of the period. Instead, it was World War II that finally permitted a radical epistemological break which went well beyond the contraposition of naturalism and historicism. Also apparent elsewhere, the radical rupture was particularly emphatic in Italy and Germany, where totalitarian ideology, after its military defeat, rang especially hollow.

92 Enzo Traverso, A ferro e fuoco: La guerra civile europea 1914-45 (Bologna: II Mulino, 2007). 